\title{
Does ALK-rearrangement predict favorable response to the therapy of bevacizumab plus pemetrexed in advanced non-small-cell lung cancer? Case report and literature review
}

\author{
Zhichao Liu' ${ }^{1,2 \dagger}$, Youting Bao ${ }^{2,3 \dagger}$, Butuo Li ${ }^{2}$, Xindong Sun ${ }^{2}$ and Linlin Wang ${ }^{2 *}$ (1)
}

\begin{abstract}
Background: Advanced ALK-rearranged non-small cell lung cancer (NSCLC) patients will develop acquired resistance after anaplastic lymphoma kinase (ALK) inhibitors therapies. Vascular endothelial growth factor-A (VEGF-A) production and tumor vessel formation were found to be more significantly enriched in ALK-rearrangement NSCLC than that in epidermal growth factor receptor or Kirsten rat sarcoma viral oncogene mutated NSCLC. However, the correlation between ALK rearrangement and the efficacy of bevacizumab (a recombinant humanized IgG1 monoclonal antibody targeting VEGF-A) was still elusive.
\end{abstract}

Case presentation: We report a case with metastatic NSCLC harboring ALK-rearrangement who was initially resistant to two courses of ALK-Tyrosine Kinase Inhibitor (TKI) therapy, but got a clinical benefit of 7 months of progression free survival after the combined treatment of bevacizumab plus pemetrexed. And the patient tolerated well.

Conclusions: It suggested that bevacizumab combined with pemetrexed might be a preferred option for ALK rearrangement patient who had failed no less than two courses of ALK-TKIs.

Keywords: ALK, ALK inhibitor resistance, Non-small cell lung cancer, Pemetrexed, Bevacizumab

\section{Background}

Patients diagnosed as anaplastic lymphoma kinase (ALK) rearrangement comprise $3-7 \%$ of non-small cell lung cancer (NSCLC) cases [1]. Rearrangements of the ALK gene lead to an oncogene addicted state due to the aberrant ALK activation. Three generations of ALK target inhibitors, including crizotinib, ceritinib, alectinib and lorlatinib, have been developed and used in targeted therapy; and ALK positive patients could get longer progression free survival (PFS) and better objective response rate (ORR)

\footnotetext{
*Correspondence: wanglinlinatjn@163.com

†Zhichao Liu and Youting Bao contributed equally to this work

${ }^{2}$ Department of Radiation Oncology, Shandong Cancer Hospital

Affiliated to Shandong University, Shandong Academy of Medical

Science, No. 440, Ji Yan Road, Jinan 250017, Shandong, China

Full list of author information is available at the end of the article
}

of $53-65 \%$ compared to the cellular toxic chemotherapy [2-6]. However, almost all patients will develop acquired resistance inevitably. Thus, the option of next therapeutic strategies is problematic in particular with regard to its insensitivity to various standard chemotherapies.

Bevacizumab targeting tumor angiogenesis showed encouraging efficacy as the first-line therapy for patients with advanced non-squamous NSCLC [7]. Epidermal Growth Factor Receptor (EGFR) mutation-positive patients had a significantly longer PFS on bevacizumab compared with wild type EGFR patients in NSCLC [8]. However, the correlation between ALK rearrangement and the efficacy of bevacizumab was still elusive. Besides, it has been showed that patients with ALK-positive tumor status seemed to have a better prognosis when treated with pemetrexed [9]. And adding pemetrexed 
to bevacizumab was associated with a significant PFS benefit compared with bevacizumab alone in patients with non-squamous NSCLC. However, few studies have focused on the combination of bevacizumab with pemetrexed in ALK-positive patients.

Here, we presented a case with ALK positive lung adenocarcinoma getting significant clinical benefit from bevacizumab to pemetrexed combination therapy who had failed two courses of ALK-inhibitor therapy.

\section{Case presentation}

A 55-year-old Asian never-smoker female presenting with an irritable dry cough for a month was examined in a community hospital in October 2013. Computed tomography $(\mathrm{CT})$ scan of chest revealed a single pulmonary nodule (approximately $2.5 \times 5 \mathrm{~cm}$ ) on the lower left lobe and enlarged subcarinal lymph nodes (Fig. 1a, b). No metastases in brain, liver, bone and so on were found. After biopsy of the left lung lesion, she was diagnosed as lung moderately differentiated adenocarcinoma (Fig. 1c) and the stage was IIIA (cT2N2M0).

She was recommended for two cycles of inducing chemotherapy with docetaxel $\left(75 \mathrm{mg} / \mathrm{m}^{2} \mathrm{D} 1-\mathrm{D} 1=\mathrm{D} 21\right)$ and cisplatin $\left(75 \mathrm{mg} / \mathrm{m}^{2} \mathrm{D} 1-\mathrm{D} 1=\mathrm{D} 21\right)$ and then the concurrent radiotherapy and chemotherapy (Fig. 2). However, the primary lesion on the lower left lobe was larger and new metastasis in the right upper lobe was found after these two cycle chemotherapy (Fig. 3). Re-evaluation and genotype testing of the left lung lesion showed no EGFR mutation, but luckily, the strong expression of ALK (ventana); and EML4-ALK gene fusion was positive by fluorescence in situ hybridization (Fig. 4).

The patient received crizotinib treatment $(250 \mathrm{mg}$, bid, orally) starting from 7 Jan. 2014 (Fig. 2). The primary lesion on the lower left lobe and metastasis in the right upper lobe was disappeared 1 month later. Stable condition maintained until 30 Jun. 2014 when metastatic nodules were found on liver (Fig. 5a, e, i). Microwave ablation was used to treat with these metastatic nodules. And crizotinib was continued until 20 Aug. 2014, when liver lesions enlarged again (Fig. 5b, f, j).

Then the patient began to receive ceritinib $(750 \mathrm{mg}$, qd, orally) from 8 Oct. 2014 (Fig. 2); 1 month later, the liver metastasis shrinked apparently (partial response, PR) (Fig. 5c, g, k). However, adverse events including acute liver function lesion (CTCAE) (grade 2/CTCAE ver. 4.0)
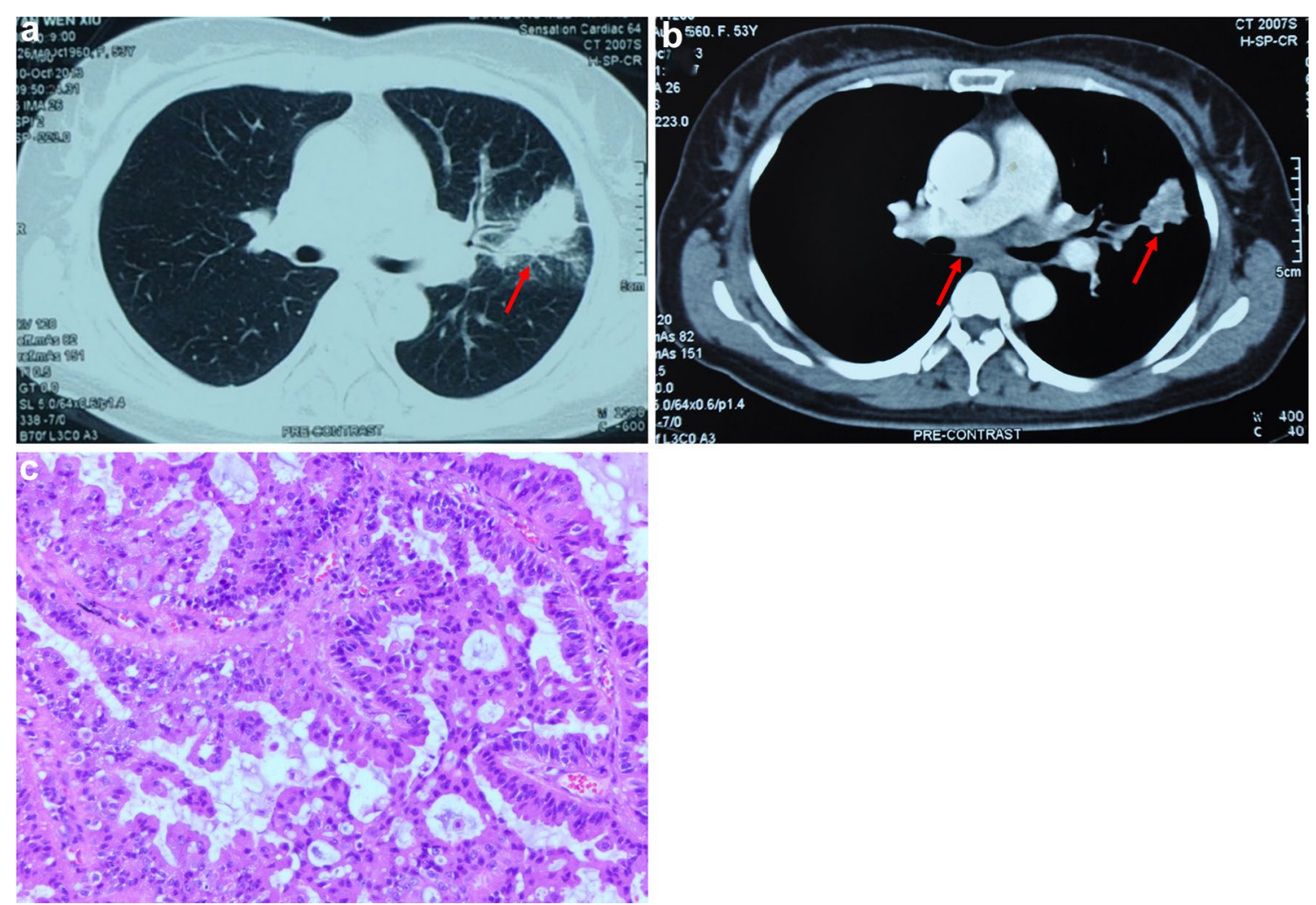

Fig. 1 The Chest CT images and histology of the left lung neoplasm. a Pulmonary window revealed a single pulmonary nodule on the lower left lobe. b Mediastinal window revealed the single pulmonary nodule on the lower left and enlarged subcarinal lymph nodes. $\mathbf{c}$ Hematoxylin and eosin staining demonstrated adenocarcinoma (magnification $\times 200$ ) 


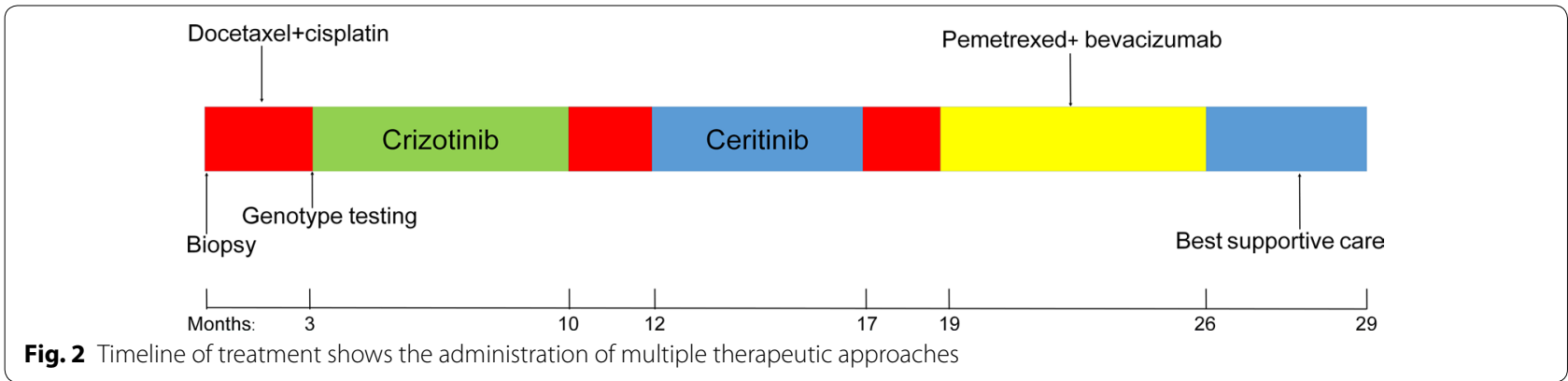

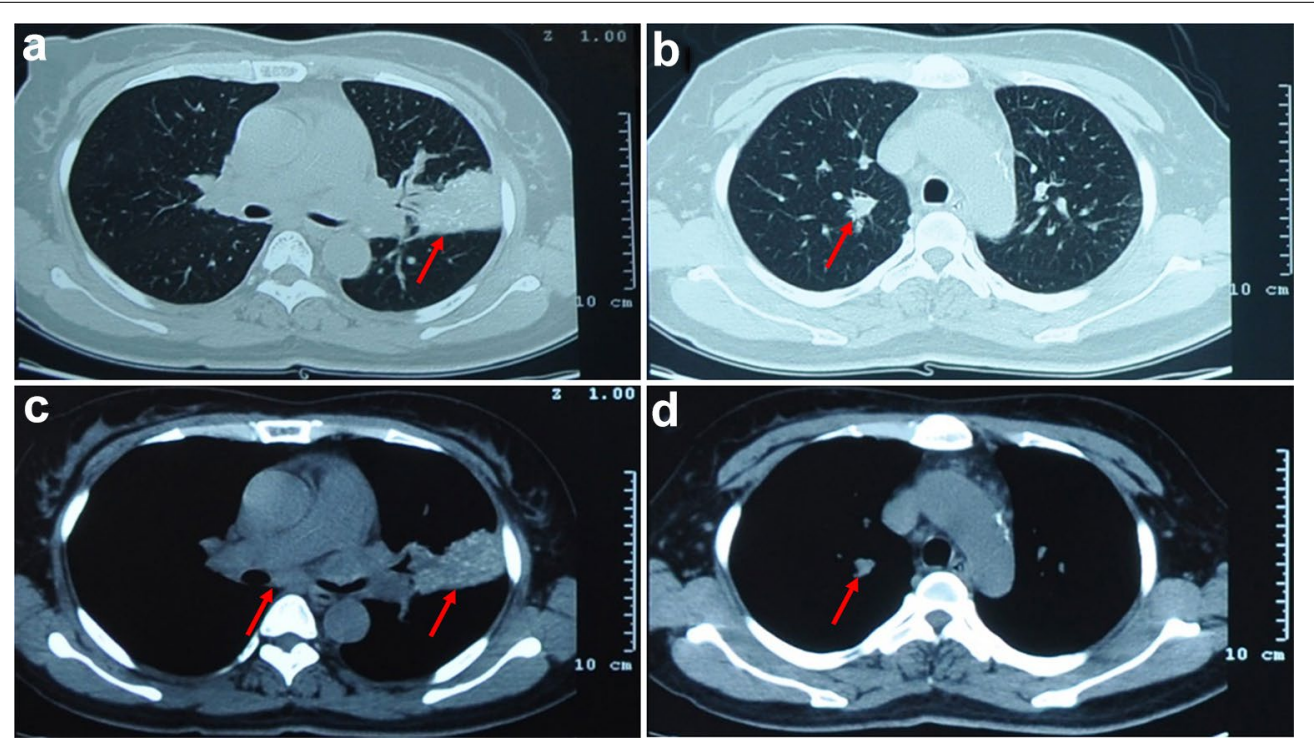

Fig. 3 Imaging examination confirmed the disease progression after two cycle inducing chemotherapy. a, c The primary lesion on the lower left lobe was larger than before. $\mathbf{b}, \mathbf{d}$ New metastasis in the right upper lobe was found

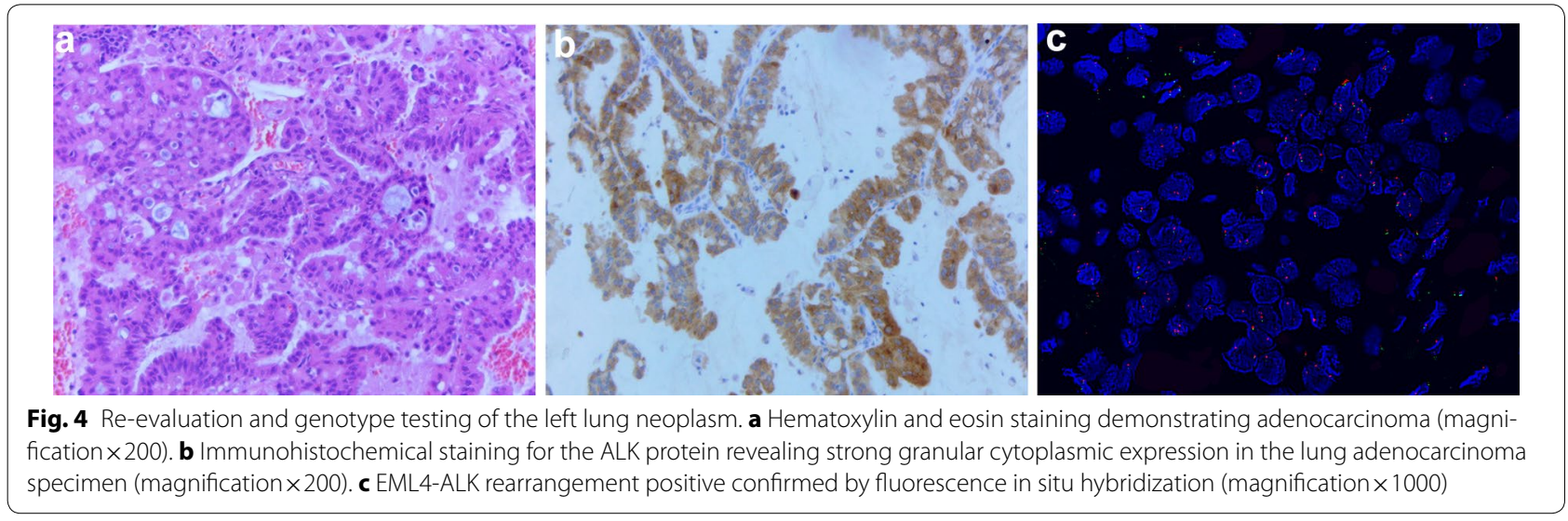

and severe diarrhea occurred. The ceritinib dose was then decreased from 750 to $450 \mathrm{mg}$. Although there were no other metastases, the treatment was discontinued because of liver metastasis progression in March 2015 (Fig. 5d, h, l).
The patient came to our hospital on 4 May 2015 (Fig. 6a, d, g). After the re-biopsy of liver metastasis, three EML4-ALK resistance mutations (C1156Y, D1203N and L1198F) was found. The patient began to receive treatment of pemetrexed $\left(500 \mathrm{mg} / \mathrm{m}^{2} \mathrm{D} 1-\mathrm{D} 1=\mathrm{D} 21\right)$ with 


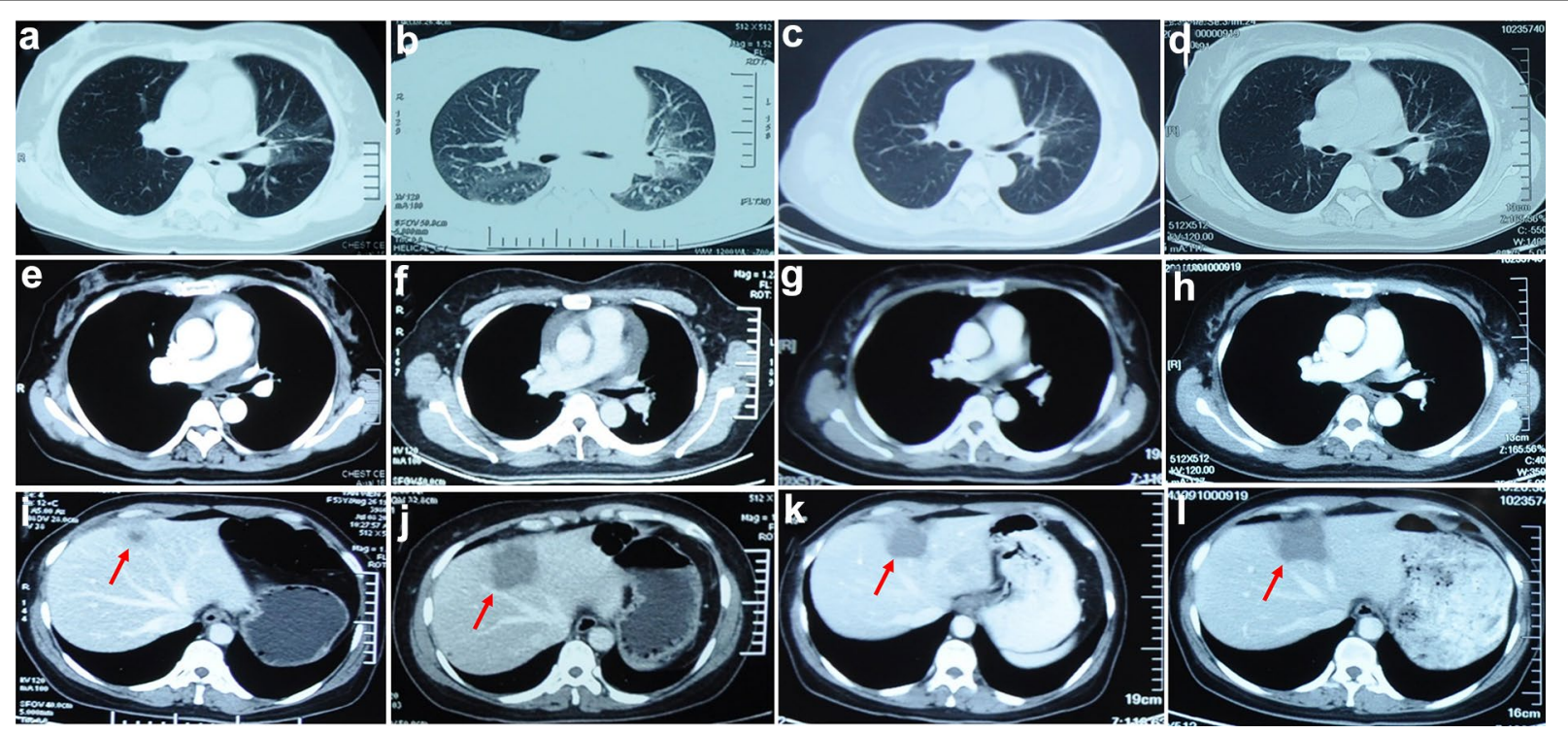

Fig. 5 Disease evaluation during the treatment of crizotinib and ceritinib. $\mathbf{a}-\mathbf{h}$ The CT scan revealed complete remission of lung lesions. $\mathbf{i} A$ single liver nodule was found after the 6 months of starting crizotinib. $\mathbf{j}$ The enlarged liver lesions was revealed on 20 Aug. 2014. $\mathbf{k}$ The liver metastasis shrinked after the treatment of ceritinib. IThe liver lesions enlarged again after the 5 months of starting ceritinib

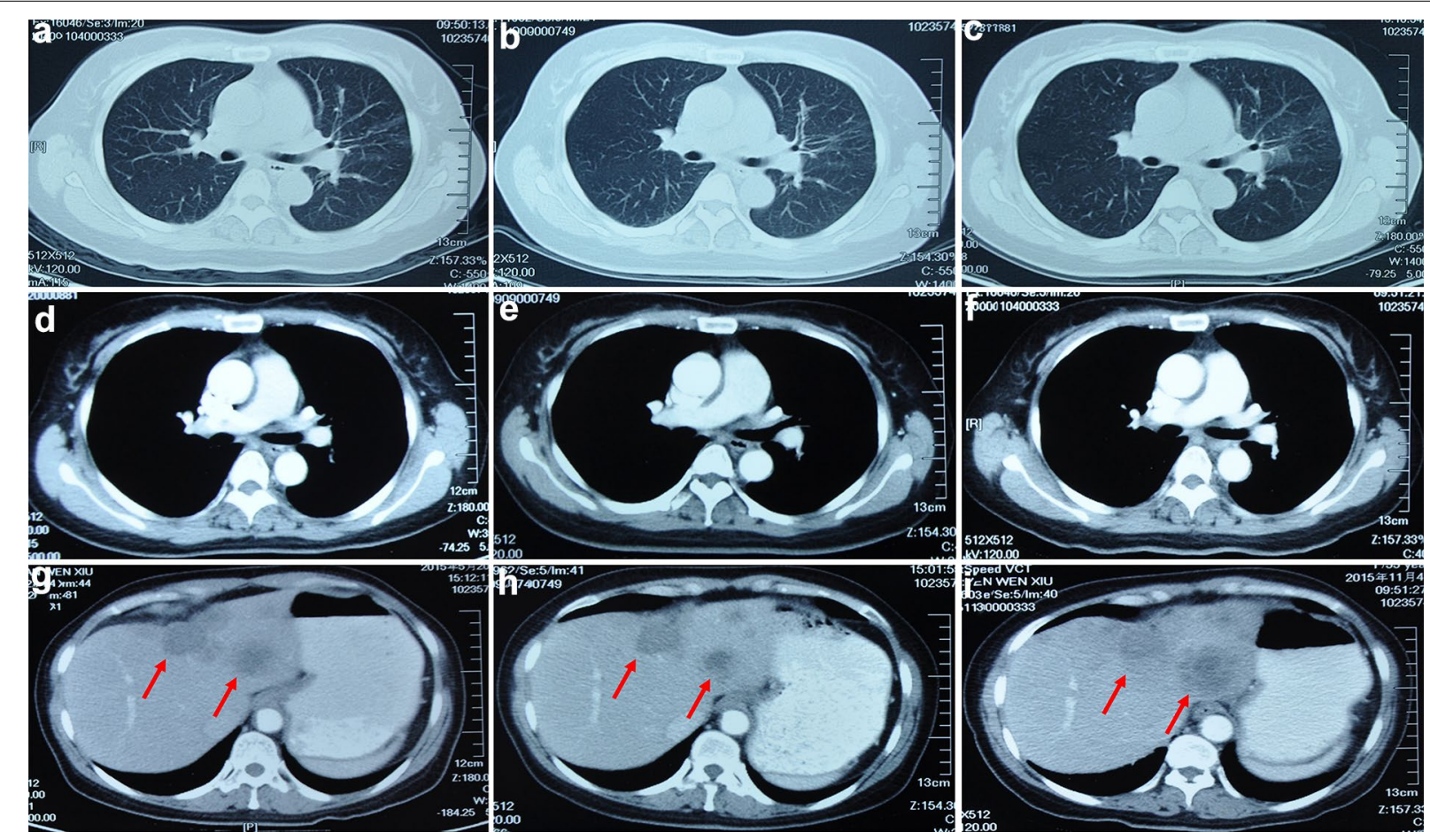

Fig. 6 Disease evaluation during the treatment of pemetrexed with bevacizumab. Before treatment of pemetrexed with bevacizumab, liver metastases were assessed using CT scan and no lung lesions were found (a, d, and $\mathbf{g})$. After two cycle therapy of pemetrexed with bevacizumab, metastatic nodule size in liver decreased (partial response) (b, e and $\mathbf{h}$ ). The CT scan showed the disease progression in liver metastases after eight cycle administration of pemetrexed plus bevacizumab (c, $\mathbf{f}$ and $\mathbf{i})$. During the entire course, there were still no metastases in bilateral lungs, mediastinum, brain and so on 
bevacizumab $\left(5 \mathrm{mg} / \mathrm{m}^{2} \mathrm{D} 1-\mathrm{D} 1=\mathrm{D} 21\right)$ from 11 May 2015 (Fig. 2). After two cycle treatment, metastatic nodule size in liver decreased, and there were no new metastases in bilateral lungs, brain and so on, which demonstrated the disease of PR (Fig. 6b, e, h). After four and six cycle treatment, the CT scan both revealed stable disease. The patient tolerated well and the performance status is 1 . Following additional two cycle of pemetrexed with bevacizumab, the liver metastatic tumor showed radiographic progression by the CT scan on 4 Dec. 2015 (Fig. 6c, f, i). The best supportive care was administrated, and the patient ultimately died of liver failure in March 2016 (Fig. 2).

\section{Discussion}

ALK rearrangement, a distinctive subset of NSCLC, is associated with several distinctive clinical and pathologic features including younger in age, never/light smoking with adenocarcinoma, men in gender, more likely to have abundant signet ring cells and absence of EGFR and Kirsten rat sarcoma viral oncogene (KRAS) mutations [10]. Crizotinib has been acknowledged as standard first line option for ALK-rearranged NSCLC, demonstrating a response rate of $60-74 \%$ and a median PFS of 7-11 months based on the "PROFILE" clinical trial program (Table 1) [5, 6, 11-18]. Besides, second generation ALK-inhibitors, ceritinib or alectinib, also have shown a significantly superior median PFS versus second line traditional chemotherapy (pemetrexed or docetaxel) when the patients have the progressed disease (Table 1) $[5,6,11-18]$. However, patients will almost inevitably relapse and the therapeutic options are thus more limited after the treatment of first and second generation ALK-inhibitors.

There are multiple mechanisms of resistance to the second generation ALK-inhibitors [19]. Mutations in the ALK tyrosine kinase domain are the main reason for the resistance, which have been identified in approximately

Table 1 Trials about the efficacy of first- and second-generation ALK inhibitors

\begin{tabular}{|c|c|c|c|c|c|c|c|}
\hline Study & $\begin{array}{l}\text { Phase } \\
\text { of study }\end{array}$ & Treatment & $\begin{array}{l}\text { Number } \\
\text { of patients }\end{array}$ & ORR (\%) & PFS (months) & Patient population & References \\
\hline PROFILE 1001 & I & Crizotinib & 149 & 60.8 & 10 & $\begin{array}{l}125 \text { of } 149 \text { ALK rearranged } \\
\text { patients had disease pro- } \\
\text { gression on } \geq 1 \text { chemo- } \\
\text { therapy }\end{array}$ & {$[5]$} \\
\hline PROFILE 1005 & $\|$ & Crizotinib & 261 & 60 & 8.1 & $\begin{array}{l}\text { ALK rearranged patients had } \\
\text { disease progression on } \geq 1 \\
\text { chemotherapy }\end{array}$ & {$[6]$} \\
\hline PROFILE 1007 & III & $\begin{array}{l}\text { Crizotinib vs docetaxel or } \\
\text { pemetrexed }\end{array}$ & $\begin{array}{l}173 \\
174\end{array}$ & $\begin{array}{l}65 \\
20\end{array}$ & $\begin{array}{l}7.7 \\
3.0\end{array}$ & $\begin{array}{l}\text { ALK rearranged patients } \\
\text { previously treated with } \\
\text { chemotherapy (platinum } \\
\text { doublet) }\end{array}$ & {$[11]$} \\
\hline PROFILE 1014 & III & $\begin{array}{l}\text { Crizotinib vs pemetrexed } \\
\text { +cispaltin/carboplatin }\end{array}$ & $\begin{array}{l}172 \\
171\end{array}$ & $\begin{array}{l}74 \\
45\end{array}$ & $\begin{array}{l}10.9 \\
7.0\end{array}$ & $\begin{array}{l}\text { Treatment-naive ALK rear- } \\
\text { ranged patients }\end{array}$ & {$[12]$} \\
\hline ASCEND3 & $\|$ & Ceritinib & 124 & 63.7 & 11.1 & $\begin{array}{l}\text { ALK rearranged patients ALK } \\
\text { inhibitor-naive but had } \\
\text { disease progression on } \\
\text { chemotherapy. }\end{array}$ & {$[13]$} \\
\hline ASCEND4 & III & $\begin{array}{l}\text { Ceritinib vs pemetrexed } \\
\text { +cispaltin/carboplatin }\end{array}$ & $\begin{array}{l}189 \\
187\end{array}$ & $\begin{array}{l}72.5 \\
26.7\end{array}$ & $\begin{array}{l}16.6 \\
8.1\end{array}$ & $\begin{array}{l}\text { Treatment-naive ALK rear- } \\
\text { ranged patients }\end{array}$ & {$[14]$} \\
\hline ASCEND5 & III & $\begin{array}{l}\text { Ceritinib vs docetaxel or } \\
\text { pemetrexed }\end{array}$ & $\begin{array}{l}231 \\
116\end{array}$ & $\begin{array}{l}39.1 \\
6.9\end{array}$ & $\begin{array}{l}5.4 \\
1.6\end{array}$ & $\begin{array}{l}\text { ALK rearranged patients } \\
\text { previously treated With } \\
\text { chemotherapy (platinum } \\
\text { doublet) and crizotinib }\end{array}$ & {$[15]$} \\
\hline J-ALEX & III & Crizotinib vs alectinib & $\begin{array}{l}104 \\
103\end{array}$ & $\begin{array}{l}70.2 \\
85.4\end{array}$ & $\begin{array}{l}10.2 \\
20.3 \text {-not } \\
\text { reached }\end{array}$ & $\begin{array}{l}\text { Treatment-naive ALK rear- } \\
\text { ranged patients }\end{array}$ & {$[16]$} \\
\hline NP28763 & $\|$ & Alectinib & 138 & 50 & 8.9 & $\begin{array}{l}\text { ALK rearranged patients } \\
\text { previously treated with } \\
\text { chemotherapy and } \\
\text { crizotinib }\end{array}$ & {$[17]$} \\
\hline NP28761 & $\|$ & Alectinib & 87 & 52.2 & 8.1 & $\begin{array}{l}\text { ALK rearranged patients } \\
\text { previously treated with } \\
\text { chemotherapy and } \\
\text { crizotinib }\end{array}$ & [18] \\
\hline
\end{tabular}


one-third of the re-biopsied tumors of these resistant patients [20]. Among these mutations, G1202R is the most common mutation type found in patients progressing on the second-generation ALK-tyrosine kinase inhibitor (TKI) [19]. Lorlatinib, an extremely selective ALK-TKI with activity also targeting ROS1 kinase, has been shown to overcome resistance mediated by the ALK G1202R secondary mutation in preclinical study. More importantly, in a phase I/II study, lorlatinib has demonstrated ORR of $46 \%$ and PFS of 9.2 months in patients pretreated with more than two courses of ALK-TKIs [2, 21]. Besides, ALK inhibitor therapy also could be tailored dependent on the variable types of mutation (Table 2) [13, 21-35]. However, treatment with lorlatinib seems very expensive in developing countries and selection of ALK-TKI based on patients' mutation type still lacks strong clinical evidence.

Pemetrexed-based chemotherapy may be another option for patients progressing on the second generation ALK-TKI. The PFS with pemetrexed based therapy for ALK-rearranged NSCLC patients is significantly longer than in patients without ALK rearrangements or with either EGFR or KRAS mutant [36-38]. Besides, pemetrexed was shown to be superior to docetaxel in both ORR ( $29 \%$ vs. $7 \%$, respectively) and PFS (4.2 months vs. 2.6 months, respectively) for ALK-rearrangement NSCLC patients progressing on platinum-based chemotherapy [5]. All of these implied that pemetrexed should be preferentially considered for the treatment of ALKrearrangement lung adenocarcinoma. However, the overall prognosis of patients with ALK-rearrangement NSCLC was still not encouraged.

Bevacizumab shows encouraging efficacy as the first or second-line therapy for patients with non-squamous NSCLC in some studies [39]. The phase III BEYOND trial compared the efficacy of carboplatin/paclitaxel plus placebo and carboplatin/paclitaxel plus bevacizumab in a Chinese patient population, and showed that the median OS was extended by 6.6 months and the median PFS was extended by 2.7 months, respectively. In particular, the median PFS was 12.4 months in EGFR mutation positive tumors and 8.3 months in wild-type tumors after the carboplatin/paclitaxel plus bevacizumab treatment [8]. However, the correlation between ALK rearrangements and the efficacy of bevacizumab remain unanswered. Besides, angiogenesis was also found to play an important role in the biology of ALK rearranged NSCLC. It has been shown that ALK-positive patients have higher levels of vascular endothelial growth factor-A (VEGF-A) and tumor vessel formations compared to EGFR and KRAS mutated NSCLC [40]. Moreover, treatment with the antiVEGF-A antibody bevacizumab strongly impaired Anaplastic Large Cell Lymphoma (containing EML4-ALK rearrangement) growth in mouse xenografts [41].

In addition, several previous clinical reports have also indicated the potential benefits of bevacizumab on advanced ALK-rearrangement NSCLC. For example, adding bevacizumab to chemotherapy was found to effectively control radioresistant brain metastases in an ALK-rearrangement lung adenocarcinoma patient [42]. Treated with bevacizumab combined chemotherapy, lung nodule of ALK-rearrangement NSCLC showed significant shrinkage after two cycles of therapy, and the PFS or OS has not been reached after 8 cycles of treatment [43]. In another retrospective study, prolonged responses (18 months) were observed after treatment of weekly paclitaxel and bevacizumab in the ALK-rearrangement NSCLC patient [44]. Finally, long-term disease control was also observed after treatment with pemetrexed and bevacizumab in NSCLC patients with ALK or ROS1 gene rearrangements compared with general nonsquamous NSCLC population [45].

Here, we presented a case with ALK positive lung adenocarcinoma getting clinical benefit of 7 months of PFS from bevacizumab to pemetrexed treatment after two failed courses of ALK-inhibitor therapy; and the toxicity was well tolerated. It seems that addition of bevacizumab to pemetrexed treatment tend to be a favorable option for the resistant ALK-rearrangement NSCLC.

However, there are still some questions to be addressed in the near future. First, at present, the patients in the "PROFILE" and "ASCEND" trials were administrated

Table 2 The resistant mutations and sensitive mutations of ALK inhibitors

\begin{tabular}{|c|c|c|c|}
\hline ALK-TKI & Sensitive mutations & Insensitive mutations & References \\
\hline Cizotinib & L1198F & $\begin{array}{l}\text { 1151Tins, L1152P, L1152R, C1156Y, I1171T, F1174C, F1174L, } \\
\text { F1174V, L1196M, G1202R, S1206, G1269, G1269S, R1275Q }\end{array}$ & {$[21-24]$} \\
\hline Ceritinib & I1171T, L1196M, S1206Y, G1269A, F1174L, V1180L & C1156Y, 1151Tins, L1152R, F1174C, G1202R, G1123S & {$[25-28]$} \\
\hline Alectinib & $\begin{array}{l}\text { 1151Tins, L1152R, C1156Y, F1174L, F1174V, L1196M, S1206Y, } \\
\text { G1269A, R1275Q }\end{array}$ & I1171T, I1171S, V1180L, G1202R & [28-32] \\
\hline Lorlatinib & $\begin{array}{l}\text { F1147L, 1151Tins, L1152R, C1156Y, L1192R, L1196M, G1202R, } \\
\text { S12026Y, G1269A }\end{array}$ & L1198F & {$[22,33-35]$} \\
\hline
\end{tabular}


standard chemotherapy or ALK-TKI as the first or second line therapies. However, none study is being planned in order to compare bevacizumab combined with chemotherapy versus ALK-TKI in the treatmentnaïve or previously treated ALK-rearrangement NSCLC patients. Second, given the effectiveness of bevacizumab and ALK-TKI in the ALK-rearrangement NSCLC, trials of NCT02521051 and NCT02946359 combing these two kinds of drugs are being undertaken [46, 47]. Third, although the patient in our report got 7 months of PFS in the fourth line treatment, the efficacy of bevacizumab plus pemetrexed for ALK-rearrangement NSCLC is still needed to be studied in future prospective trials. ALKrearrangement may predict favorable response to the therapy of bevacizumab plus pemetrexed in advanced non-small-cell lung cancer.

\section{Conclusion}

We present this case with ALK-rearrangement metastatic NSCLC who was initially resistant to two courses of ALK-TKI therapy, but got a clinical benefit from the combined treatment of bevacizumab plus pemetrexed and we conduct a review of the related literature. It demonstrates that ALK-rearrangement may predict a favorable response to the therapy of bevacizumab combined with pemetrexed in advanced non-small cell lung cancer and this combination may be a reasonable choice for advanced ALK-rearrangement NSCLC patient when ALK-TKIs treatment failed. Further studies are still needed to confirm the efficacy of bevacizumab plus pemetrexed for ALK-rearrangement NSCLC.

\section{Abbreviations \\ ALK: anaplastic lymphoma kinase; NSCLC: non-small cell lung cancer; VEGF- A: vascular endothelial growth factor-A; PFS: progression free survival; TKI: Tyrosine Kinase Inhibitor; ORR: objective response rate; EGFR: Epidermal Growth Factor Receptor; CT: computed tomography; CEA: carcinoembryonic antigen; PR: partial response; KRAS: Kirsten rat sarcoma viral oncogene.}

\section{Authors' contributions}

LW: provided the case and responsible for manuscript revision. ZL: drafted the manuscript. YB: participated in reviewing and editing of the manuscript. BL: contributed in collecting and analyzing pathological pictures. XS: contributed in analyzing CT image. All authors read and approved the final manuscript.

\section{Author details}

${ }^{1}$ School of Medicine and Life Sciences, University of Jinan-Shandong Academy of Medical Sciences, Jinan 250200, China. ${ }^{2}$ Department of Radiation Oncology, Shandong Cancer Hospital Affiliated to Shandong University, Shandong Academy of Medical Science, No. 440, Ji Yan Road, Jinan 250017, Shandong, China. ${ }^{3}$ Clinical College, Weifang Medical University, Weifang 261053, China.

\section{Acknowledgements}

This study was approved by the Ethics Committee of Shandong Cancer Hospital. Informed patient consent was obtained for publication of this case report. All authors of the manuscript have read and agreed to its content and are accountable for all aspects of the accuracy and integrity of the manuscript in accordance with ICMJE criteria.

\section{Competing interests}

The authors declare that they have no competing interests.

\section{Availability of data and materials}

All material in this commentary is stored on the institutional computer of the corresponding author (DRW) with cloud based back-up.

\section{Consent for publication}

Patient has given written consent to publish data relating to her case for educational purposes.

\section{Ethics approval and consent to participate}

Ethical approval was obtained from the Shandong Cancer Hospital Affiliated to Shandong University Research Ethics Committee. Informed consent to treatment was obtained from the patient.

\section{Funding}

This work was supported by the following grant: Natural Science Foundation of Shandong Province (Grant No. ZR2016HM41), the Project of the National Natural Science Foundation of China (Grant No. 81402299), the Project of the National Natural Science Foundation of China (Grant No. 81472812), the Project of Postdoctoral Innovation of Shandong Province (Grant No. 201501010 and 201601006), the Project of Postdoctoral Science Foundation of China (Grant No. 2016M590640).

\section{Publisher's Note}

Springer Nature remains neutral with regard to jurisdictional claims in published maps and institutional affiliations.

Received: 3 October 2017 Accepted: 22 December 2017

Published online: 09 January 2018

\section{References}

1. Soda M, Choi YL, Enomoto M, Takada S, Yamashita Y, Ishikawa S, Fujiwara S, Watanabe H, Kurashina K, Hatanaka H, Bando M, Ohno S, Ishikawa Y, Aburatani H, Niki T, Sohara Y, Sugiyama Y, Mano H (2007) Identification of the transforming EML4-ALK fusion gene in non-small-cell lung cancer. Nature 448(7153):561-566

2. Johnson TW, Richardson PF, Bailey S, Brooun A, Burke BJ, Collins MR, Cui JJ, Deal JG, Deng YL, Dinh D, Engstrom LD, He M, Hoffman J, Hoffman RL, Huang Q, Kania RS, Kath JC, Lam H, Lam JL, Le PT, Lingardo L, Liu W, McTigue M, Palmer CL, Sach NW, Smeal T, Smith GL, Stewart AE, Timofeevski S, Zhu H, Zhu J, Zou HY, Edwards MP (2014) Discovery of (10R)-7-amino-12-fluoro-2,10,16-trimethyl-15-oxo-10,15,16,17-tetrahydro2H-8,4-(metheno)pyrazolo[4,3-h][2, 5, 11]-benzoxadiazacyclotetradecine3-carbonitrile (PF-06463922), a macrocyclic inhibitor of anaplastic lymphoma kinase (ALK) and c-ros oncogene 1 (ROS1) with preclinical brain exposure and broad-spectrum potency against ALK-resistant mutations. $J$ Med Chem 57(11):4720-4744

3. Kodama T, Tsukaguchi T, Yoshida M, Kondoh O, Sakamoto H (2014) Selective ALK inhibitor alectinib with potent antitumor activity in models of crizotinib resistance. Cancer Lett 351(2):215-221

4. Shaw AT, Engelman JA (2014) Ceritinib in ALK-rearranged non-small-cell lung cancer. N Engl J Med 370(26):2537-2539

5. Camidge DR, Bang YJ, Kwak EL, lafrate AJ, Varella-Garcia M, Fox SB, Riely GJ, Solomon B, Ou SH, Kim DW, Salgia R, Fidias P, Engelman JA, Gandhi L, Janne PA, Costa DB, Shapiro GI, Lorusso P, Ruffner K, Stephenson P, Tang Y, Wilner K, Clark JW, Shaw AT (2012) Activity and safety of crizotinib in patients with ALK-positive non-small-cell lung cancer: updated results from a phase 1 study. Lancet Oncol 13(10):1011-1019

6. Kim DW, Ahn MJ, Shi Y (2012) Results of a global phase II study with crizotinib in advanced ALK-positive non-small cell lung cancer (NSCLC). J Clin Oncol 30:7533

7. Jenab-Wolcott J, Giantonio BJ (2009) Bevacizumab: current indications and future development for management of solid tumors. Expert Opin Biol Ther 9(4):507-517 
8. Zhou C, Wu YL, Chen G, Liu X, Zhu Y, Lu S, Feng J, He J, Han B, Wang J, Jiang G, Hu C, Zhang H, Cheng G, Song X, Lu Y, Pan H, Zheng W, Yin AY (2015) BEYOND: a randomized, double-blind, placebo-controlled, multicenter, phase iii study of first-line carboplatin/paclitaxel plus bevacizumab or placebo in chinese patients with advanced or recurrent non-squamous non-small-cell lung cancer. J Clin Oncol 33(19):2197-2204

9. Park S, Park TS, Choi CM, Lee DH, Kim SW, Lee JS, Kim WS, Song JS, Lee JC (2015) Survival benefit of pemetrexed in lung adenocarcinoma patients with anaplastic lymphoma kinase gene rearrangements. Clin Lung Cancer 16(5):e83-e89

10. Shaw AT, Yeap BY, Mino-Kenudson M, Digumarthy SR, Costa DB, Heist RS, Solomon B, Stubbs H, Admane S, McDermott U, Settleman J, Kobayashi S, Mark EJ, Rodig SJ, Chirieac LR, Kwak EL, Lynch TJ, lafrate AJ (2009) Clinical features and outcome of patients with non-small-cell lung cancer who harbor EML4-ALK. J Clin Oncol 27(26):4247-4253

11. Shaw AT, Kim DW, Nakagawa K, Seto T, Crino L, Ahn MJ, De Pas T, Besse B, Solomon BJ, Blackhall F, Wu YL, Thomas M, O'Byrne KJ, Moro-Sibilot D, Camidge DR, MokT, Hirsh V, Riely GJ, IyerS Tassell V, Polli A, Wilner KD, Janne PA (2013) Crizotinib versus chemotherapy in advanced ALK-positive lung cancer. N Engl J Med 368(25):2385-2394

12. Solomon BJ, MokT, Kim DW, Wu YL, Nakagawa K, Mekhail T, Felip E, Cappuzzo F, Paolini J, Usari T, Iyer S, Reisman A, Wilner KD, Tursi J, Blackhall F (2014) First-line crizotinib versus chemotherapy in ALK-positive lung cancer. N Engl J Med 371(23):2167-2177

13. Felip E, Orlov S, Park K, Yu CJ, Tsai CM, Nishio M (2015) ASCEND-3: a singlearm, open-label, multicenter phase II study of ceritinib in ALKi-naïve adult patients (pts) with ALK-rearranged (ALK+) non-small cell lung cancer (NSCLC). J Clin Oncol 33:8060

14. Soria JC, Tan DS, Chiari R, Wu YL, Paz-Ares L, Wolf J, Geater SL, Orlov S, Cortinovis D, Yu CJ, Hochmair M, Cortot AB, Tsai CM, Moro-Sibilot D, Campelo RG, McCulloch T, Sen P, Dugan M, Pantano S, Branle F, Massacesi C, de Castro G Jr (2017) First-line ceritinib versus platinum-based chemotherapy in advanced ALK-rearranged non-small-cell lung cancer (ASCEND-4): a randomised, open-label, phase 3 study. Lancet 389(10072):917-929

15. Scagliotti G, Kim TM, Crinò L (2016) Ceritinib vs chemotherapy (CT) in patients (pts) with advanced anaplastic lymphoma kinase (ALK)rearranged (ALK+) non-small cell lung cancer (NSCLC) previously treated with CT and crizotinib (CRZ): results from the confirmatory phase 3 ASCEND-5 study. Ann Oncol 27(Suppl. 6):589

16. Nokihara H, Hida T, Kondo M (2016) Alectinib (ALC) versus crizotinib (CRZ) in ALK-inhibitor naive ALK-positive non-small cell lung cancer (ALK+NSCLC): primary results from the J-ALEX study. J Clin Oncol 34:9008

17. Ou SH, Ahn JS, De Petris L, Govindan R, Yang JC, Hughes B, Lena H, MoroSibilot D, Bearz A, Ramirez SV, Mekhail T, Spira A, Bordogna W, Balas B, Morcos PN, Monnet A, Zeaiter A, Kim DW (2016) Alectinib in crizotinibrefractory ALK-rearranged non-small-cell lung cancer: a phase ii global study. J Clin Oncol 34(7):661-668

18. Shaw AT, Gandhi L, Gadgeel S, Riely GJ, Cetnar J, West H, Camidge DR, Socinski MA, Chiappori A, Mekhail T, Chao BH, Borghaei H, Gold KA, Zeaiter A, Bordogna W, Balas B, Puig O, Henschel V, Ou SH (2016) Alectinib in ALK-positive, crizotinib-resistant, non-small-cell lung cancer: a singlegroup, multicentre, phase 2 trial. Lancet Oncol 17(2):234-242

19. Gainor JF, Dardaei L, Yoda S, Friboulet L, Leshchiner I, Katayama R, Dagogo-Jack I, Gadgeel S, Schultz K, Singh M, Chin E, Parks M, Lee D, DiCecca RH, Lockerman E, Huynh T, Logan J, Ritterhouse LL, Le LP, Muniappan A, Digumarthy S, Channick C, Keyes C, Getz G, Dias-Santagata D, Heist RS, Lennerz J, Sequist LV, Benes CH, lafrate AJ, Mino-Kenudson M, Engelman JA, Shaw AT (2016) Molecular mechanisms of resistance to first- and second-generation alk inhibitors in ALK-rearranged lung cancer. Cancer Discov 6(10):1118-1133

20. Shaw AT, Engelman JA (2013) ALK in lung cancer: past, present, and future. J Clin Oncol 31(8):1105-1111

21. Li J, Sun R, Wu Y, Song M, Li J, Yang Q, Chen X, Bao J, Zhao Q (2017) L1198F mutation resensitizes crizotinib to ALK by altering the conformation of inhibitor and ATP binding sites. Int J Mol Sci 18(3):482

22. Shaw AT, Friboulet L, Leshchiner I, Gainor JF, Bergqvist S, Brooun A, Burke BJ, Deng YL, Liu W, Dardaei L, Frias RL, Schultz KR, Logan J, James LP, Smeal T, Timofeevski S, Katayama R, lafrate AJ, Le L, McTigue M, Getz G, Johnson TW, Engelman JA (2016) Resensitization to crizotinib by the lorlatinib ALK resistance mutation L1198F. N Engl J Med 374(1):54-61
23. Kanaan Z, Kloecker GH, Paintal A, Perez CA (2015) Novel targeted therapies for resistant ALK-rearranged non-small-cell lung cancer: ceritinib and beyond. Onco Targets Ther 8:885-892

24. Muller IB, De Langen AJ, Honeywell RJ, Giovannetti E, Peters GJ (2016) Overcoming crizotinib resistance in ALK-rearranged NSCLC with the second-generation ALK-inhibitor ceritinib. Expert Rev Anticancer Ther 16(2):147-157

25. Heuckmann JM, Holzel M, Sos ML, Heynck S, Balke-Want H, Koker M, Peifer M, Weiss J, Lovly CM, Grutter C, Rauh D, Pao W, Thomas RK (2011) ALK mutations conferring differential resistance to structurally diverse ALK inhibitors. Clin Cancer Res 17(23):7394-7401

26. Friboulet L, Li N, Katayama R, Lee CC, Gainor JF, Crystal AS, Michellys PY, Awad MM, Yanagitani N, Kim S, Pferdekamper AC, Li J, Kasibhatla S, Sun F, Sun X, Hua S, McNamara P, Mahmood S, Lockerman EL, Fujita N, Nishio M, Harris JL, Shaw AT, Engelman JA (2014) The ALK inhibitor ceritinib overcomes crizotinib resistance in non-small cell lung cancer. Cancer Discov 4(6):662-673

27. Toyokawa G, Inamasu E, Shimamatsu S, Yoshida T, Nosaki K, Hirai F, Yamaguchi M, Seto T, Takenoyama M, Ichinose Y (2015) Identification of a novel ALK G1123S mutation in a patient with ALK-rearranged nonsmall-cell lung cancer exhibiting resistance to ceritinib. J Thorac Oncol 10(7):e55-e57

28. Ou SH, Greenbowe J, Khan ZU, Azada MC, Ross JS, Stevens PJ, Ali SM, Miller VA, Gitlitz B (2015) 11171 missense mutation (particularly I1171N) is a common resistance mutation in ALK-positive NSCLC patients who have progressive disease while on alectinib and is sensitive to ceritinib. Lung Cancer 88(2):231-234

29. Katayama R, Friboulet L, Koike S, Lockerman EL, Khan TM, Gainor JF, lafrate AJ, Takeuchi K, Taiji M, Okuno Y, Fujita N, Engelman JA, Shaw AT (2014) Two novel ALK mutations mediate acquired resistance to the next-generation ALK inhibitor alectinib. Clin Cancer Res 20(22):5686-5696

30. Ou SH, Milliken JC, Azada MC, Miller VA, Ali SM, Klempner SJ (2016) ALK F1174V mutation confers sensitivity while ALK 11171 mutation confers resistance to alectinib. The importance of serial biopsy post progression. Lung Cancer 91:70-72

31. Ignatius Ou SH, Azada M, Hsiang DJ, Herman JM, Kain TS, Siwak-Tapp C, Casey C, He J, Ali SM, Klempner SJ, Miller VA (2014) Next-generation sequencing reveals a novel NSCLC ALK F1174V mutation and confirms ALK G1202R mutation confers high-level resistance to alectinib (CH5424802/RO5424802) in ALK-rearranged NSCLC patients who progressed on crizotinib. J Thorac Oncol 9(4):549-553

32. Song Z, Wang M, Zhang A (2015) Alectinib: a novel second generation anaplastic lymphoma kinase (ALK) inhibitor for overcoming clinicallyacquired resistance. Acta Pharm Sin B 5(1):34-37

33. Sullivan I, Planchard D (2016) ALK inhibitors in non-small cell lung cancer: the latest evidence and developments. Ther Adv Med Oncol 8(1):32-47

34. Liao BC, Lin CC, Shih JY, Yang JC (2015) Treating patients with ALK-positive non-small cell lung cancer: latest evidence and management strategy. Ther Adv Med Oncol 7(5):274-290

35. Zou HY, Friboulet L, Kodack DP, Engstrom LD, Li Q, West M, Tang RW, Wang H, Tsaparikos K, Wang J, Timofeevski S, Katayama R, Dinh DM, Lam H, Lam JL, Yamazaki S, Hu W, Patel B, Bezwada D, Frias RL, Lifshits E, Mahmood S, Gainor JF, Affolter T, Lappin PB, Gukasyan H, Lee N, Deng S, Jain RK, Johnson TW, Shaw AT, Fantin VR, Smeal T (2015) PF-06463922, an ALK/ROS1 inhibitor, overcomes resistance to first and second generation ALK inhibitors in preclinical models. Cancer Cell 28(1):70-81

36. CamidgeDR Kono SA, Lu X, Okuyama S, Baron AE, Oton AB, Davies AM, Varella-Garcia M, Franklin W, Doebele RC (2011) Anaplastic lymphoma kinase gene rearrangements in non-small cell lung cancer are associated with prolonged progression-free survival on pemetrexed. J Thorac Oncol 6(4):774-780

37. Ma D, Hao X, Wang Y, Xing P, Li J (2016) Clinical effect of pemetrexed as the first-line treatment in Chinese patients with advanced anaplastic lymphoma kinase-positive non-small cell lung cancer. Thorac Cancer 7(4):452-458

38. Duchemann B, Friboulet L, Besse B (2015) Therapeutic management of ALK + non-small cell lung cancer patients. Eur Respir J 46(1):230-242

39. Cohen MH, Gootenberg J, Keegan P, Pazdur R (2007) FDA drug approval summary: bevacizumab (Avastin) plus carboplatin and paclitaxel as first-line treatment of advanced/metastatic recurrent non-squamous non-small cell lung cancer. Oncologist 12(6):713-718 
40. Dejean E, Renalier MH, Foisseau M, Agirre X, Joseph N, de Paiva GR, Al Saati T, Soulier J, Desjobert C, Lamant L, Prosper F, Felsher DW, Cavaille J, Prats H, Delsol G, Giuriato S, Meggetto F (2011) Hypoxia-microRNA-16 downregulation induces VEGF expression in anaplastic lymphoma kinase (ALK)-positive anaplastic large-cell lymphomas. Leukemia 25(12):1882-1890

41. Martinengo C, Poggio T, Menotti M, Scalzo MS, Mastini C, Ambrogio C, Pellegrino E, Riera L, Piva R, Ribatti D, Pastorino F, Perri P, Ponzoni M, Wang Q, Voena C, Chiarle R (2014) ALK-dependent control of hypoxiainducible factors mediates tumor growth and metastasis. Cancer Res 74(21):6094-6106

42. Su YL, Rau KM (2015) Adding bevacizumab to chemotherapy effectively control radioresistant brain metastases in ALK-positive lung adenocarcinoma. J Thorac Oncol 10(4):e21-e22

43. Wang H, Zhu H, Kong L, Yu J (2016) Efficacy of cisplatin/pemetrexed with bevacizumab to treat advanced lung adenocarcinoma with different drive genes: case report and literature review. Onco Targets Ther 9:4639-4644

44. Habib S, Delourme J, Dhalluin X, Petyt G, Tacelli N, Scherpereel A, Lafitte JJ, Cortot AB (2013) Bevacizumab and weekly paclitaxel for non-squamous non-small cell lung cancer patients: a retrospective study. Lung Cancer 80(2):197-202

45. Liang Y, Wakelee HA, Neal JW (2015) Relationship of driver oncogenes to long-term pemetrexed response in non-small cell lung cancer. Clin Lung Cancer 16(5):366-373

46. Arms and Interventions. https://clinicaltrials.gov/ct2/show/NCT02521051 ?term $=$ NCT02521051\&rank=1. Accessed 22 Sep 2017

47. Arms and Interventions. https://clinicaltrials.gov/ct2/show/NCT02946359 ?term $=$ NCT02946359\&rank=1. Accessed 22 Sep 2017

\section{Submit your manuscript to a SpringerOpen ${ }^{\circ}$ journal and benefit from:}

- Convenient online submission

- Rigorous peer review

- Open access: articles freely available online

- High visibility within the field

- Retaining the copyright to your article

Submit your next manuscript at $\boldsymbol{\nabla}$ springeropen.com 